\title{
SUBSTRATES AND WATER AVAILABILITY ON THE EMERGENCE AND INITIAL GROWTH OF Alibertia sessilis Schum. SEEDLINGS
}

\author{
Leandro Henrique de Sousa Mota ${ }^{1}$, Silvana de Paula Quintão Scalon ${ }^{2}$, Rafael Heinz ${ }^{1}$, Daiane Mugnol Dresch ${ }^{3}$ \\ ${ }^{1}$ Agricultural engineer, MA in Plant Production, Federal University of Grande Dourados/School of Agricultural Sciences. Dourados-Mato \\ Grosso do Sul, Brazil - leandro.mota@syngenta.com; heinz_rafael@yahoo.com.br \\ ${ }^{2 *}$ Federal University of Grande Dourados/School of Agricultural Sciences. Dourados, Mato Grosso do Sul, Brazil - \\ silvanascalon@ufgd.edu.br \\ ${ }^{3}$ Agricultural engineer, Post-doctoral student (PNPD) at UFGD/FCA. Dourados, Mato Grosso do Sul, Brazil - daiamugnol@ hotmail.com
}

Received for publication: 06/06/2017 - Accepted for publication: 07/10/2017

\begin{abstract}
The cultivation of native species in the Cerrado has encountered various problems, for instance, the slow growth and the lack of knowledge about the cultivation practices. In order to better use the available water resources and to produce quality seedlings, this study aimed to evaluate different substrates and water levels on the emergence and initial growth of Alibertia sessilis Schum. seedlings. The effects of the following substrates were evaluated: dystroferric Red Latosol (Oxisol), Oxisol +sand (1:1 v/v), Oxisol + sand + semidecomposed poultry litter $(1: 1: 0.5 \mathrm{v} / \mathrm{v})$, Oxisol + sand $2+$ semi-decomposed poultry litter $(1: 2: 0.5 \mathrm{v} / \mathrm{v})$ and Oxisol + commercial-substrate-CS (1:1 v/v) associated with the levels of irrigation of 25, 50, 75 and 100\% of the water holding capacity in the substrate (WHC). The best results for emergence percentage, initial growth and quality of seedlings were observed in the substrates Oxisol + sand $2+$ poultry litter $(1: 2: 0,5)$ at $100 \%$ of WHC. There was no emergence at $25 \%$ of WHC.
\end{abstract}

Keywords: Rubiaceae; marmelinho; fruit of the Cerrado.

\section{Resumo}

Substratos e disponibilidade hídrica na emergência e crescimento inicial de mudas de Alibertia sessilis Schum. O cultivo de espécies nativas no Cerrado tem esbarrado em vários problemas, entre eles, o crescimento lento e a carência de conhecimentos sobre as práticas culturais. A fim de melhor utilizar os recursos hídricos disponíveis e produzir mudas de qualidade, objetivou-se no presente trabalho avaliar diferentes substratos e níveis de água na emergência e no crescimento inicial das mudas Alibertia sessilis Schum. Foram avaliados os efeitos dos substratos Latossolo Vermelho distroférrico (LVd), LVd +areia (1:1 $\mathrm{v} / \mathrm{v}), \mathrm{LVd}+$ areia + cama de frango semidecomposta $(1: 1: 0,5 \mathrm{v} / \mathrm{v}), \mathrm{LVd}+$ areia 2 + cama de frango semidecomposta $(1: 2: 0,5 \mathrm{v} / \mathrm{v})$ e LVd + substrato comercial -SC (1:1 v/v) associados aos níveis de irrigação de 25, 50, 75 e 100\% da capacidade de retenção de água no substrato (CRA). Os melhores resultados para porcentagem de emergência, crescimento inicial e qualidade das mudas foram observados nos substratos LVd + areia $2+$ cama de frango (1:2:0,5) a 100\% da CRA. Não houve emergência a 25\% da CRA.

Palavras-chave: Rubiaceae; marmelinho; frutífera do Cerrado.

\section{INTRODUCTION}

The cultivation and production of seedlings of native species in the Cerrado have encountered several problems, such as slow growth, basic information about their biology, forest utilization, management, cultivation treatments, and lack of awareness of their economic potential (SCALON; JEROMINE, 2013; NUNES et al., 2014, SCALON et al., 2015, GORDIN et al., 2016).

Some studies have already been conducted addressing the effect of substrates and water levels on the emergence and production of seedlings of some native species in the Cerrado, with varying results observed. In the species Hancornia speciosa, the substrates dystroferric Red Latosol (Oxisol), Oxisol + sand (1:1) or Oxisol + Bioplant $^{\circledR}(1: 1)$ can be recommended for the emergence and initial growth of plants in water availability from $75 \%$ to $100 \%$ of WHC (GORDIN et al., 2016). For the production of Campomanesia adamantium seedlings, the best substrate was the mixture of dystroferric Red Latosol (Oxisol) + sand + Bioplant ${ }^{\circledR}(1: 1: 1 \mathrm{v} / \mathrm{v})$ at $75 \%$ and $100 \%$ of the water holding capacity in the substrate (DRESCH et al., 2016). However, for the species Eugenia pyriformis, the highest percentages of emergence and better plant growth were observed in the substrate of dystroferric Red Latosol (Oxisol)+ sand + poultry litter (1:2:0.5 v:v:v) at 50\% of WHC (SCALON; JEROMINE, 2013).

FLOREST A, Curitiba, PR, v. 47, n. 4, p. 513 - 522, out/dez. 2017.

Mota, L. H. S. et al.

ISSN eletrônico 1982-4688

DOI: $10.5380 /$ rf.v47i4.53083 
Studies on the relationship water-plant can feed into greater knowledge of the processes of absorption, transport and water loss, and provide strategies of management of plants grown in environments subject to deficit or excess of water in the soil. The amount of water stored and available to these plants varies, among other factors, with the amount of organic matter and texture of the substrate. The plants will respond differently to each condition for cultivation, especially concerning growth, quality, and metabolism (SCALON; JEROMINE, 2013; ROCHA et al., 2016; DRESCH et al., 2016).

The substrates usually used to produce seedlings may consist of a mixture of mineral and organic components. Different substrate formulations have been used to produce seedlings, such as mixtures containing humus, carbonized rice hull, chicken manure, coffee husk, charcoal, and Plantmax ${ }^{\circledR}$ (DRESCH et al., 2016; SCALON; JEROMINE, 2013; GORDIN et al., 2016). The poultry litter has been utilized in many regions where the broiler farming is well developed, which generates large availability of organic waste. The addition of organic matter to the soil provides greater moisture to the soil in cultivation under irrigation suspension (ROCHA et al., 2016), as well as contributes to the physical-chemical properties of the soil, such as cation exchange capacity, the formation of complexes and chelates with numerous ions, improving structure, aeration and retention of moisture (FORNASIERI FILHO, 1992).

The Alibertia sessilis (Vell.) K. Schum. - Rubiaceae, known as "marmelinho" or "marmelo-do-cerrado", is a sub-bush species and demonstrates great food and medicinal importance (RODRIGUES; CARVALHO, 2001). Its fruits are consumed in natura or used as jellies and pies by the regional population, its leaves are eaten by cattle. Additionally, along with its branches, its leaves are used in medicinal preparations, as compress, bath, and poultice and are employed to heal skin affections (ALMEIDA et al., 1998). Thus, as for most species of the Cerrado, there is little information on the process of seedling formation of this species and its potential for use in projects to recover degraded areas.

Considering the hardiness of this species, we hypothesized that it is a hydrically little demanding and that its cultivation is easily carried out in substrates poor in organic matter. Thus, we aimed to assess if different substrates and water levels affect the emergence and initial growth of seedlings of Alibertia sessilis.

\section{MATERIAL AND METHODS}

The exsiccata of the botanical material is deposited in the Herbarium of the Federal University of Grande Dourados (UFGD) under the Number 5410. The fruits of A. sessilis were collected when they were mature with a coat of brown coloring. The collection was held at Fazenda Santa Madalena, located in DouradosMS, at $23^{\circ} 8^{\prime} 17^{\prime}$ 'S and $55^{\circ} 8^{\prime} 15^{\prime}$ ' $\mathrm{W}$, featuring an elevation of $436 \mathrm{~m}$ with typical vegetation of the Cerrado. After collecting the fruits, they were processed on a sieve with running water to remove the pulp and to select the whole seeds without external signs of injury or deformation. The selected seeds were dried on a sieve in the shade in a laboratory environment and the sowing occurred on the following day.

The sowing was performed on the substrates: 1) dystroferric Red Latosol (Oxisol) ; 2) Oxisol + sand $(1: 1 \mathrm{v} / \mathrm{v}) ; 3)$ Oxisol + sand + semi-decomposed poultry litter $(1: 1: 0.5 \mathrm{v} / \mathrm{v})$; 4) Oxisol + sand $2+$ semidecomposed poultry litter (1:2:0.5 v/v); and 5) Oxisol + commercial substrate - - CS (1:1 v/v), without any additional chemical fertilization on any substrate. The commercial substrate was composed of pine bark, coconut fiber, vermiculite, and macro-and micronutrients, which were not disclosed by the manufacturer, with a $\mathrm{pH}$ between 5.2 and 6.5 and the electrical conductivity between 0.6 and $1.4 \mu \mathrm{s} \mathrm{cm}^{-1}$. The semi-decomposed poultry litter was in fermentation for around 60 days, humification phase of the organic material.

The levels of $25 \%, 50 \%, 75 \%$ and $100 \%$ of the water holding capacity were used in the irrigation, which was performed on alternate days. The water holding capacity (WHC) was determined by adopting the content of water retained by the substrate after drainage of the excess (SOUZA et al., 2000).

The seeds with no pre-germination treatment were sown in $50 \times 190 \mathrm{~mm}$ tubes at a depth of $2 \mathrm{~cm}$ and kept in greenhouse under plastic screen to avoid the incidence of rainfall, and the brightness was reduced in $30 \%$.

In the design of experiments, completely randomized designs in schema of subdivided plot were used. The plot consisted of each of the five substrates, and the subplot consisted of each of the four water levels. Four repetitions of twenty seeds were used for each treatment.

The percentage and emergence speed index (ESI) (NAKAGAWA, 1999) were assessed and the assessments lasted 60 days after sowing. 175 days after emergence, the seedlings were assessed for growth and quality, being determined: stem height $(\mathrm{cm})$ and root length $(\mathrm{cm})$ using graduated ruler; root collar diameter $(\mathrm{mm})$ with digital caliper; chlorophyll content (SPAD), measured with the instrument chlorophyll meter SPAD 502; leaf area $\left(\mathrm{cm}^{2}\right)$, using Leaf Area Meter LCO 3000; dry mass of root and aerial part (g), using Forced-Air Oven at $60^{\circ} \mathrm{C}$; height: diameter ratios of the root collar (HDR); ratio of the shoot dry mass , and the root dry 
mass (RPAR); f Dickson quality index (DQI), according to the formula [total dry matter / (HDR + RPAR)] (DICKSON et al., 1960).

After a normality test (Lilliefors Test) and a homogeneity test (Bartlett's Test) to analyze the variance of the characteristics studied, emergence percentage data were transformed into $\sqrt{(x+1)}$. The results were submitted to variance analysis and, when the effect showed significant, the means obtained were compared by the test of Tukey at $5 \%$ of probability. The analyses were performed using the computer program SISVAR (Ferreira, 2011).

\section{RESULTS}

There was no emergence in the lowest water holding capacity (25\%), therefore, this treatment was not considered in the statistical analysis of any characteristic assessed. The seeds of Alibertia sessilis took about 50 days to cease the emergence (data not shown), presenting low percentage and ESI by the end of this period (Figure 1a and 1b).

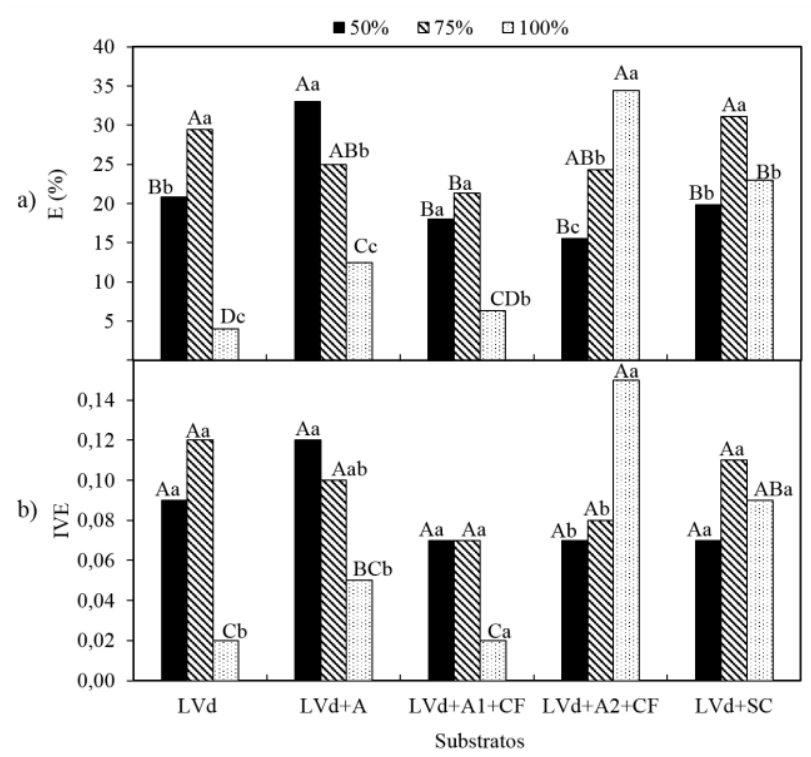

Figure 1. Percentage of emergence (E) and emergence speed index (IVE) of Alibertia sessilis Schum. seeds due to different substrates and water holding capacity (CRA). Uppercase letters compare the same CRA in different substrates, and lowercase letters compare the different CRA in the same substrate. LVd = distroferric Red Latosol; $\mathrm{A}=$ sand; $\mathrm{CF}=$ semi-decomposed poultry litter; $\mathrm{SC}=$ commercial substrate.

Figura 1. Porcentagem de emergência (E) e índice de velocidade de emergência (IVE) das sementes de Alibertia sessilis Schum. em função de diferentes substratos e capacidade de retenção de água (CRA). Letras maiúsculas comparam a mesma CRA nos diferentes substratos e letras minúsculas comparam as diferentes CRA no mesmo substrato. $\mathrm{LVd}=$ latossolo Vermelho distroférrico; $\mathrm{A}=$ areia; $\mathrm{CF}=$ cama de frango semidecomposta; $\mathrm{SC}=$ substrato comercial.

The highest values of percentage of emergence and ESI were observed in the cultivation in Oxisol + S2+ PL (1:2:0.5) and 100\% of the WHC, with values that did not vary significantly from the cultivation in Oxisol + sand at 50\% WHC. The results varied in the different substrates and water levels assessed, showing lower values in the substrate Oxisol and $100 \%$ WHC.

It can be observed that 175 days after emergence, the height of seedlings was higher when cultivated at $100 \%$ WHC in the substrate Oxisol + CS (Figure 2a). Similar results were observed for the diameter of the root collar (Figure 2b) that did not change when compared to that of seedlings grown in Oxisol + S2 + PL. $+\mathrm{S}$ (Figure 2c).

Root length was higher when grown with less water availability (50\% WHC) and in the substrate Oxisol 


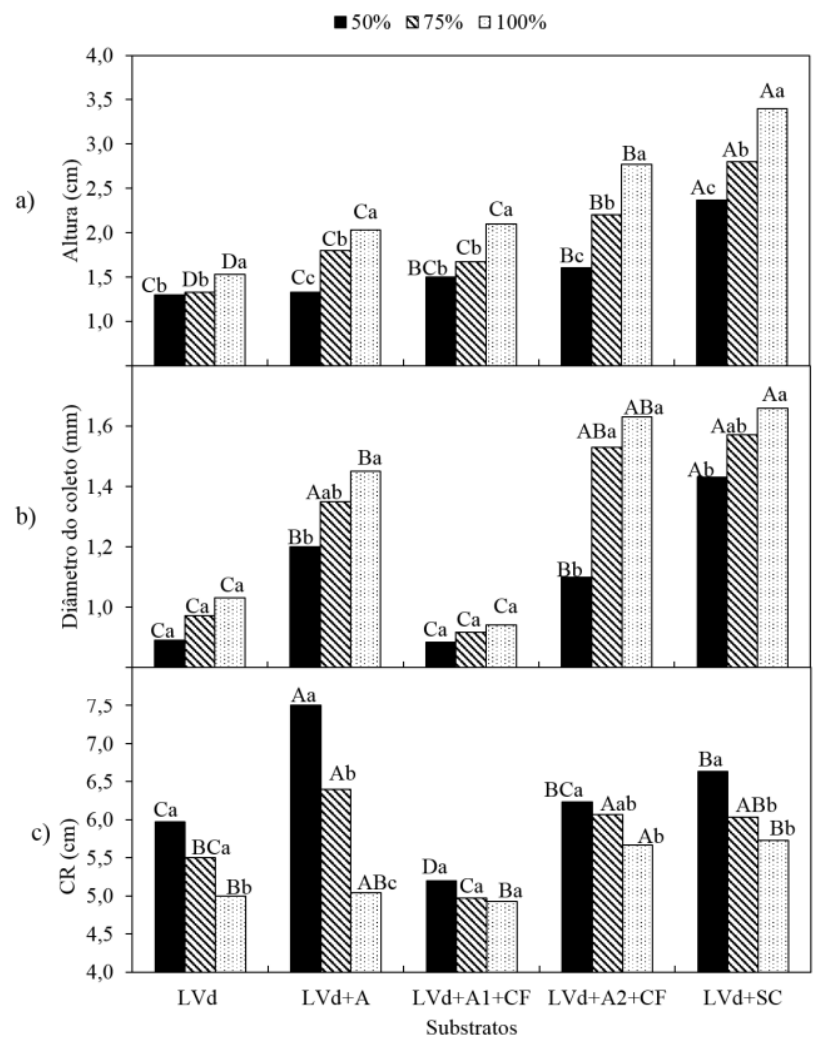

Figure 2. Height (a), diameter of the root collar (b) and root length - CR (c) of Alibertia sessilis Schum seedlings. due to different substrates and water holding capacity (CRA). Uppercase letters compare the same CRA in different substrates, and lowercase letters compare the different CRA in the same substrate. $\mathrm{LVd}=$ distroferric Red Latosol; $\mathrm{A}=$ sand; $\mathrm{CF}=$ semi-decomposed poultry litter; $\mathrm{SC}=$ commercial substrate.

Figura 2. Altura (a), diâmetro do coleto (b) e comprimento da raiz - CR (c), de mudas de Alibertia sessilis Schum. em função de diferentes substratos e capacidade de retenção de água (CRA). Letras maiúsculas comparam a mesma CRA nos diferentes substratos e letras minúsculas comparam as diferentes CRA no mesmo substrato. $\mathrm{LVd}=$ latossolo Vermelho distroférrico; $\mathrm{A}=$ areia; $\mathrm{CF}=$ cama de frango semidecomposta; $\mathrm{SC}=$ substrato comercial.

Both the chlorophyll content and the leaf area were lower in the seedlings grown at $50 \%$ of WHC on virtually all assessed substrates (Figure $3 a$ and $3 b$ ). In the substrate Oxisol + S2 + PL (1:2:0,5), SPAD was higher in all levels of water holding capacity assessed (Figure 3a), showing no variation from the substrate Oxisol + CS at $100 \%$ of WHC.

Shoot and root dry mass were higher in substrates containing more sand and poultry litter (Oxisol + S2 + PL) or when commercial substrate was added (Oxisol + CS) at 75 and 100\% of WHC (Figure 4a and b). Although the root length was higher under 50\% WHC, this behavior was not repeated for the dry mass. 


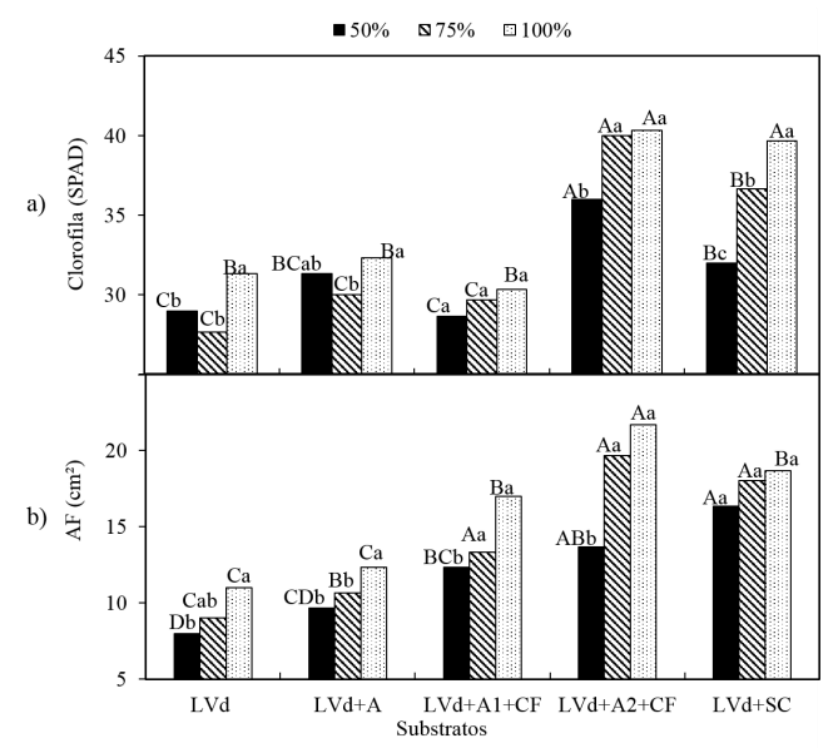

Figure 3. SPAD index (a) and leaf area - AF (b) of Alibertia sessilis Schum. seedlings due to different substrates and water holding capacity (CRA). Uppercase letters compare the same CRA in different substrates, and lowercase letters compare the different CRA in the same substrate. $\mathrm{LVd}=$ distroferric Red Latosol; $\mathrm{A}=$ sand; $\mathrm{CF}=$ semi-decomposed poultry litter; $\mathrm{SC}=$ commercial substrate.

Figura 3. Índice de clorofila (a) e área foliar - AF (b) de mudas de Alibertia sessilis Schum. em função de diferentes substratos e capacidade de retenção de água (CRA). Letras maiúsculas comparam a mesma CRA nos diferentes substratos e letras minúsculas comparam as diferentes CRA no mesmo substrato. $\mathrm{LVd}=$ latossolo Vermelho distroférrico; $\mathrm{A}=$ areia; $\mathrm{CF}=$ cama de frango semidecomposta; $\mathrm{SC}=$ substrato comercial.

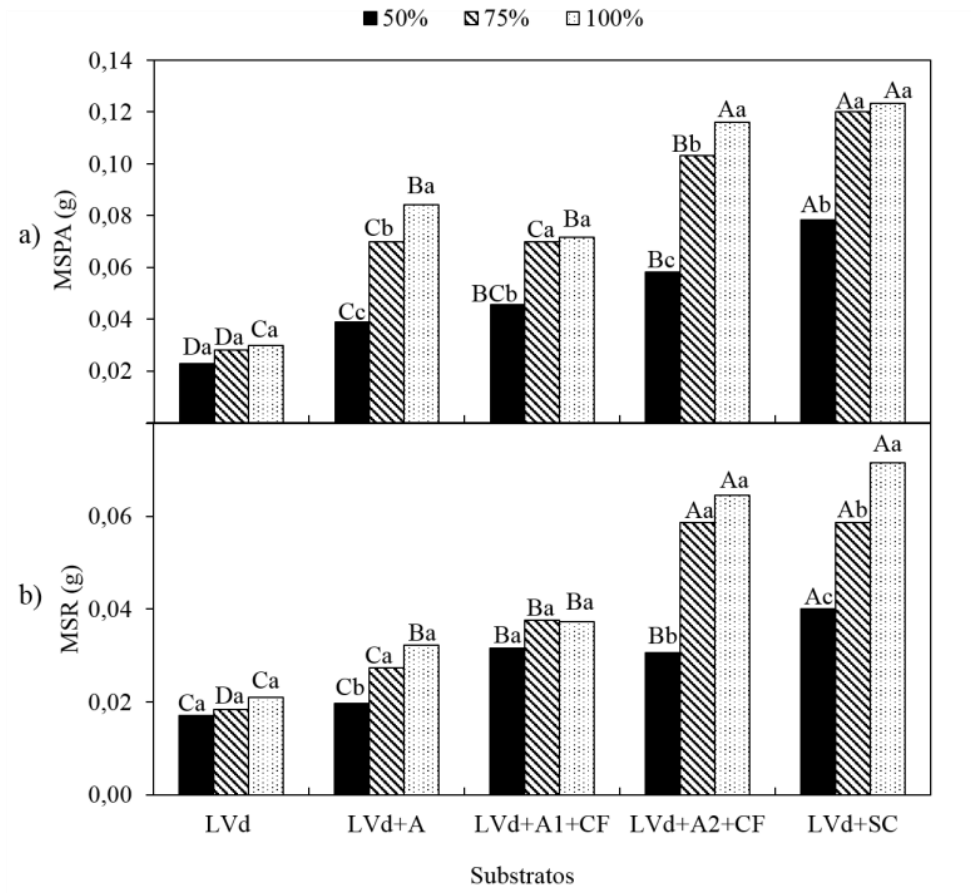

Figure 4. Shoot dry mass (a) and root (b) of Alibertia sessilis Schum. seedlings due to different substrates and water holding capacity (CRA). Uppercase letters compare the same CRA in different substrates, and lowercase letters compare the different CRA in the same substrate. LVd = distroferric Red Latosol; $\mathrm{A}=$ sand $\mathrm{CF}=$ semi-decomposed poultry litter; $\mathrm{SC}=$ commercial substrate. 
Figura 4. Massa seca da parte aérea (a) e raiz (b) de mudas de Alibertia sessilis Schum. em função de diferentes substratos e capacidade de retenção de água (CRA). Letras maiúsculas comparam a mesma CRA nos diferentes substratos e letras minúsculas comparam as diferentes CRA no mesmo substrato. LVd = latossolo Vermelho distroférrico; $\mathrm{A}=$ areia; $\mathrm{CF}=$ cama de frango semidecomposta; $\mathrm{SC}=$ substrato comercial.

The relation aerial parts/root (RAPR) did not vary significantly between the different levels of WHC (Figure 5a). We observed that the higher the root dry mass the lower was the relation aerial parts/root.

However, in the relation height/diameter (RHD), it was higher under larger water availability, especially in the substrates Oxisol $+\mathrm{S} 2+\mathrm{PL}$ and Oxisol $+\mathrm{CS}$ (Figure 5b). The highest values of Dickson quality index were obtained in seedlings grown in substrates Oxisol + S2 + PL and Oxisol + CS and under 75\% and 100\% of WHC (Figure 5c).
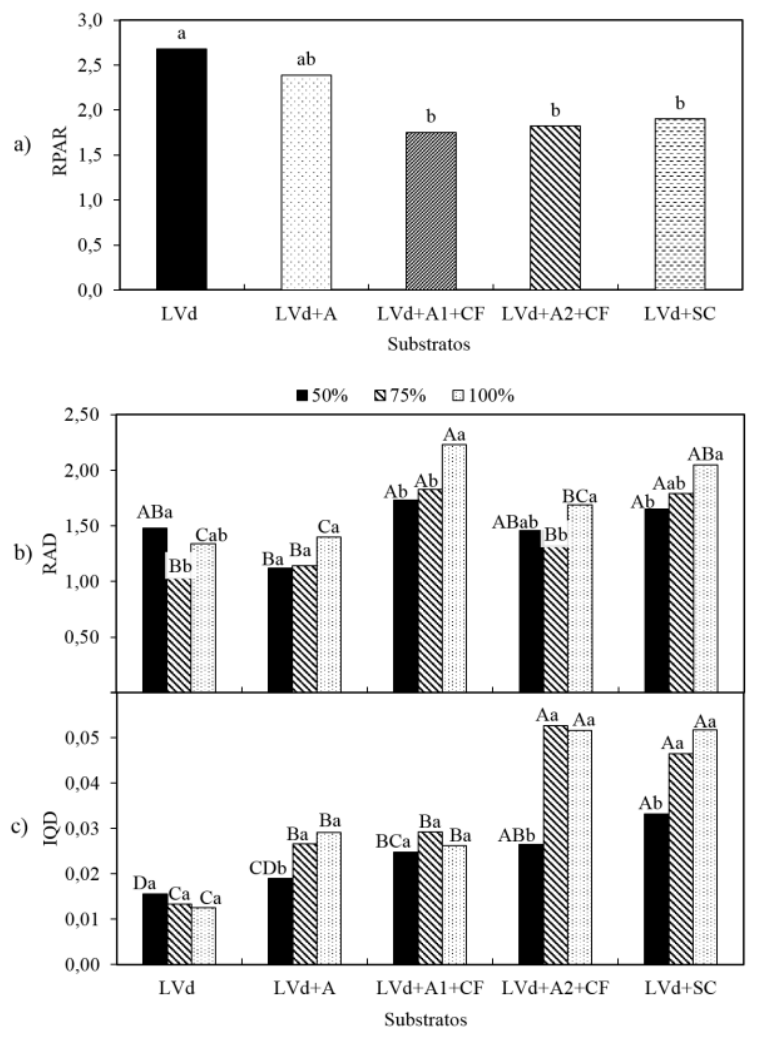

Figure 5. Relation aerial parts/root - RPAR (a), relation height /diameter (b), and Dickson quality index -IQD (c) in Alibertia sessilis Schum seedlings. due to different substrates and water holding capacity - CRA (b, c). Uppercase letters compare the same CRA in different substrates, and lowercase letters compare the different CRA in the same substrate. LVd = distroferric Red Latosol; $\mathrm{A}=$ sand; $\mathrm{CF}=$ semidecomposed poultry litter; $\mathrm{SC}=$ commercial substrate.

Figura 5. Relação massa seca da parte aérea/ raiz - RPAR (a), relação altura /diâmetro (b) e índice de qualidade de Dickson - IQD (c) em mudas de Alibertia sessilis Schum. em função de diferentes substratos e capacidade de retenção de água - CRA $(b, c)$. Letras maiúsculas comparam a mesma CRA nos diferentes substratos e letras minúsculas comparam as diferentes CRA no mesmo substrato. LVd = latossolo Vermelho distroférrico; $\mathrm{A}=$ areia; $\mathrm{CF}=$ cama de frango semidecomposta; $\mathrm{SC}=$ substrato comercial.

\section{DISCUSSION}

Seeds of Alibertia sessilis showed low germination potential independent of substrates and tested water holding capacities. It is observed in the literature that the germination potential of the species of the genus Alibertia is quite variable; for example the seeds of A. edulis under controlled temperature conditions of $20^{\circ}, 25^{\circ}$ and $30^{\circ} \mathrm{C}$ in BOD presented from 91 to $81 \%$ of germination and from 0,52 to 0,48 of GSI (NUNES et al., 
2014).It has been observed in the literature, that the potential germination of the species of the genus Alibertia is quite variable; for example the seeds of A. edulis under controlled temperature conditions of 20,25 and $30^{\circ} \mathrm{C}$ in BOD, have 91 to $81 \%$ germination and 0,52 to 0,48 for the IVG (NUNES et al., 2014). However, they may present, on average, $20 \%$ to $80 \%$ of germination and reduction in the germination potential, which was attributed to the temperature and storage time associated with seed moisture content (BENEDICT et al., 2016). Thus, these differences between both species of the same genus and of the same native environment can be attributed to the seed water level at the time of sowing or as according to the time in which the seeds were stored after harvesting and processing before sowing.

The water restriction in the cultivation at $25 \%$ WHC impaired imbibition and metabolism of the $A$. sessilis embryonic axis since this condition affects the speed and percentage of germination of the seeds by reducing cell expansion. It is noteworthy that the increased water supply caused by $100 \%$ of WHC also impaired germination and growth processes, which may be due to the reduction of soil oxygenation. The limitations to the diffusion of oxygen may cause the germination to stop by favoring the ethanol production in the cells of the embryonic axis, which is toxic to the normal metabolism due to acidification and death of the seeds (KOLB; JOLY, 2010).

The lowest values of emergence in the substrate containing only distroferric Red Latosol and at $100 \%$ of WHC may be ascribed to the clayey characteristic of this type of soil, triggering the lowest water and aeration availability for the seeds when the substrate was maintained at $100 \%$ of WHC. Similarly, this water holding capacity also reduced the emergence percentage and the ESI of Eugenia pyriformis (SCALON; JEROMINE, 2013), which was also attributed to the reduction of aeration of the substrate.

The best germination results observed in substrates containing addition of poultry litter and sand, especially in greater proportion, are attributed to the beneficial effect of the addition of organic matter and sand in the substrate. This result has been reported in the literature for other species, as this mixture presents materials that enable good porosity and drainage in their composition, which allow the movement of water and air in the substrate and favor the germination and emergence (FORNASIERI FILHO, 1992; SILVA et al., 2009; SCALON; JEROMINE, 2013; GORDIN et al., 2016).

In this sense, when assessing the effect of different substrates on the production of seedlings of Hancornia speciosa, Silva et al. (2009) observed better germination in the substrate with carbonized rice hull, which provided better drainage and, consequently, better aeration. In order to produce seedlings of Eugenia pyriformis, the substrate should be composed of distroferric Red Latosol + sand + poultry litter $(1: 2: 0,5)$ (SCALON; JEROMINE, 2013).

In addition to affecting the germination processes, the water restriction due to WHC of $50 \%$ reduced the growth of seedlings of $A$. sessilis. Lowest water availability leads to decreased cell expansion, caused by dehydration of the protoplast, and increased concentration of the solutes (MARTINS et al., 2010). As a consequence of dehydration, morphological, physiological and metabolic modifications are observed through the whole plant, which affect the production and translocation of photoassimilates to the new growth areas (SAPETA et al, 2013).

The highest root growth of seedlings observed under lower water availability in the substrate corroborates the information from literature, which suggests higher synthesis of abscisic acid in the cells of the root tissue of species under this condition. This triggers greater expansion and, consequently, higher root growth, although this higher growth is not accompanied by mass accumulation (TAIZ; ZEIGER, 2013). This response enables deepening of the root system and greater soil exploration, which leads, as a consequence, to the obtention of water and nutrients that the plant needs. However, the lower root growth in substrate with high WHC, depending on the type of soil used in the seedlings cultivation, suggests that the high water availability and the very clayey characteristic of Oxisol may have caused a restriction or barrier to the development of the root system of the seedlings, which is associated with deficient aeration to supply the growth activities.

The plants grown in substrate containing poultry litter and commercial substrate presented higher chlorophyll content, which may be related to the higher nitrogen content found in the mixture. This nutrient is an important constituent of the chlorophyll molecule. However, in the substrate Oxisol + sand + poultry litter $(1: 1$ $: 0,5)$, the results were not satisfactory due to the lower proportion of sand, an important component for good aeration of the substrate. The reduction of chlorophyll levels of seedlings submitted to the holding capacity of $50 \%$ occurs due to the lower synthesis of pigments since no yellowing or leaf abcission were observed. Plants submitted to water deficit present lower content of photosynthetic pigments, which may be attributed to the degradation of chlorophyll or to the deficiency in the synthesis by the reduction of chlorophyllase (GHOLAMI et al., 2012, ASHARAF; HARRIS, 2013).

The smallest leaf area was observed in cultivated plants under lower water availability (similar to the accumulation of dry mass). Gordin et al. (2016) observed in their review that, as the leaf expansion is a process

FLORESTA, Curitiba, PR, v. 47, n. 4, p. 513 - 522, out/dez. 2017.

Mota, L. H. S. et al.

ISSN eletrônico 1982-4688

DOI: $10.5380 /$ rf.v47i4.53083 
governed by the cell turgor under water deficit, a reduction in the leaf expansion and size can occur. It would lead to the decrease in the photosynthetic activity and, consequently, to the accumulation of dry mass and plant growth.

In relation to the accumulation of biomass in the shoot and root part, we observed that the seedlings of A. sessilis presented a similar behavior when cultivated in substrates containing poultry litter + sand or commercial substrate; a more balanced distribution of mass (around 1.5 times) between the shoot and root part was observed, as on the relation RAPR. The seedlings with higher root biomass are more likely to survive water stress in the dry season once in their natural environment. The greater the development of the root system the greater the chance of surviving in the field since the seedling presents better absorption of water and support on the soil (LIMA et al., 2008). Thus, we believe that seedlings of $A$. sessilis cultivated under these conditions would have good chances of survival when transplanted.

The highest height of the seedlings observed in the cultivation with higher water availability in the substrates containing poultry litter and commercial substrate provided greater shoot dry mass, which was reflected in the RAPR and HDR calculation. However, it should be noted that a growth twice as high as the aerial part in relation to the diameter is not a favorable feature, and it is characterized as etiolation. In this condition, the plant may not be able to sustain itself and fall on very windy days, or due to any other adverse factor. Camera and Endress (2008) comment that the HDR indicates the quality of seedlings to be carried to the field. The ideal is that a balance between these characteristics exists.

The impaired effect of water deficit on the growth of $A$. sessilis has also been reported for other native species. The seedlings of Hymeneae. courbaril L. develop better in irrigation depths from 90 to $100 \%$ of potential evapotranspiration, and the water deficit reduces the height, diameter, leaf area and shoot dry mass of the seedlings (SILVA et al., 2016). Seedlings of Campomanesia adamantium and Hancornia speciosa also grow better when grown in $75 \%$ and $100 \%$ of WHC; however cultivation under water restrictions $(25 \%$ and $50 \%$ WHC) causes growth reduction (DRESCH et al., 2016; GORDIN et al., 2016).

Cultivation in substrate containing Oxisol + Sand $2+$ PL and Oxisol + CS under 75\% and 100\% of WHCprovided the best conditions for production of seedlings of $A$. sessilis, because, besides the increasing of chlorophyll content and leaf area, characteristics that are not computed in the DQI calculation, it was the condition that provided the highest DQI of the seedlings. However, it is important to emphasize the slow growth because the plants had, on average, only $4 \mathrm{~cm}$ in height in the best cultivation condition at the end of 175 days after emergence. The DQI is a good indicator of quality of seedlings since the balance of the biomass distribution, an important parameter to be used in the assessment of the quality, is considered in its calculation; besides it was used to assess the quality of seedlings of several native species of the Cerrado (SCALON; JEROMINI, 2013, DRESCH et al., 2016, GORDIN et al., 2016). However, it should be noted that the DQI was lower than the minimum value of 0.20 , as recommended by Hunt, under all conditions of cultivation (1990). Nevertheless, it is considered that the higher the DQI the better the quality of the seedlings (CESAR et al., 2014).

Although native species of the Cerrado have germination potential, they present slow growth, which can lead to a late emergence or even low survival rate. In this work, a great non-uniformity was observed in the stand of the seedlings of $A$. sessilis, which has also been observed for other native fruits species in the Cerrado.

Thus, the results confirm the hypothesis of the work and suggest that A. sessilis germinate in substrate that is poor in organic matter and has low water availability (50\% of WHC), a condition that represents its natural occurrence environment. However, if cultivated in environment with very sandy soil and availability of organic matter, the species needs higher water availability (100\% WHC).

In order to optimize its growth, the cultivation with higher water availability (75 and 100\% of WHC) and the addition of organic matter present in the semi-decomposed poultry litter or in the commercial substrate are recommended. These results suggest that, despite being a native species of an environment with low organic matter availability in the soil and subject to water deficit at some seasons of the year (as a characteristic of the Cerrado region where it is found), the species responds positively to higher water availability and organic matter in the seedlings production phase.

\section{CONCLUSIONS}

- The substrates Oxisol + sand at 50\% of WHC and Oxisol + sand $2+$ poultry litter (1:2:0.5 v/v) at $100 \%$ of WHC provide the highest percentages of emergence.

- The seedlings present higher quality and shoot growth at 175 days after the emergence on the substrates Oxisol + sand $2+$ poultry litter (1:2:0.5 v/v) and Oxisol + CS at 75, and 100\% of WHC.

\section{ACKNOWLEDGEMENTS}


To the National Council for Scientific and Technological Development (CNPq) and the Coordination for the Improvement of Higher Education Personnel (CAPES) for the granted scholarship and to the Foundation to Support the Development of Education, Science and Technology of the State of Mato Grosso do Sul (FUNDECT) for the financial assistance.

\section{REFERENCES}

ALMEIDA, S. P.; PROENÇA, C. E. B.; SANO, S. M.; RIBEIRO, J. F. Savanna: plant species useful. Planaltina: Embrapa-CPAC, 1998. 464 p.

ASHARAF, M.; HARRIS, P. J. C. Photosynthesis under stressful environments: An overview. Photosynthetica, Heidelberg, v. 51, p. 163-190, 2013.

BENTO, L. F.; DRESCH, D. M.; SCALON, S. P. Q.; MASETTO, T. E. M. Storage of Alibertia edulis seeds: Influence of water content and storage conditions. African Journal Agricultural Research, v. 11, n. 8, p. 1646$1655,2016$.

CÂMARA, C. A.; ENDRES, L. Development of seedlings of two tree species: Mimosa caesalpiniifolia Benth. and Sterculia foetida L. under different levels of shading in nursery. Floresta, Curitiba, v. 38, n. 1, p. 43-51, 2008.

CÉSAR, F. R. C. F.; MATSUMOTO, S. N.; VIANA, A. E. S.; BONFIM, J. A. Early growth and quality of seedlings of Pterogyne nitens Tull. conducted under different levels of restriction luminous artificial. Ciência Florestal, Santa Maria, v. 24, p. 357-366, 2014.

DICKSON, A.; LEAF, A. L.; HOSNER, J. F. Quality appraisal of white spruce and white pine seedlings stock in nurseries. Forest Chronicle, Mattawa, v. 36, p. 10-13, 1960.

DRESCH, D. M.; SCALON, S. P. Q.; MUSSURY, R. M.; KODAMA, F. M. Initial growth of Campomanesia adamantium (Cambess.) O. Berg. seedlings on substrates with different compositions and water retention capacities . Bioscience Journal, Uberlândia, v. 32, n. 1, p. 1-10, 2016.

FERREIRA, D. F. SISVAR: A computer statistical analysis system. Ciência e Agrotecnologia, Lavras, v. 35, n. 6, p. 1039-1042, 2011.

FORNASIERI FILHO, D. 1992. A cultura do milho. Funep, Jaboticabal, São Paulo. 273 p.

GHOLAMI, M.; RAHEMI, M.; RASTEGAR, S. Use of rapid screening methods for detecting drought tolerant cultivars of fig (Ficus carica L.). Scientia Horticulturae, Amsterdam, v. 143, p. 7-14, 2012.

GORDIN, C. R. B.; MARQUES, R. F.; SCALON, S. P. Q. Emergence and initial growth of Hancornia speciosa (Gomes) seedlings with different substrates and water availability. Amazonian Journal of Agricultural and Environmental Sciences / Journal of Agricultural Science, Belém, v. 59, n. 4, p. 352-361, 2016.

HUNT, G. A. Effect of styroblock design and cooper treatment on morphology on conifer seedlings. In: Rose R, Campbell SJ, Landis TD (eds) Proceedings of the Target Seedling Symposium, Meeting of the Western Forest Nursery Associations Western Forest Nursery Association, Colorado, pp. 218-222, 1990.

KOLB, R. M.; JOLY, C. A. Germination and anaerobic metabolism of seeds of Tabebuia cassinoides (Lam.) DC subjected to flooding and anoxia. Flora, Jena, v. 205, no. 2, p. 112-117, 2010.

LIMA, J. D.; SILVA, B. M. S.; MORAES, W. S.; DANTAS, V. A. V.; ALMEIDA, C. C. Effects of light on growth of seedlings of Caesalpinia ferrea Mart. ex Tul. (Leguminosae, Caesalpinoideae). Acta Amazonica, Manaus, v. 38, n. 1, p. 5-10, 2008.

MARTINS, M. O.; NOGUEIRA, R. J. M. C.; AZEVEDO NETO, A. D.; SANTOS, M. G. Growth of young plants Neem-the Indian (Azadirachta indica a. juss. - Meliaceae) under different regimes of water. Revista Árvore, Viçosa, v. 34, n. 5, p. 771-779, 2010.

NAKAGAWA, J. Testes de vigor baseados no desempenho de plântulas. In: KRZYZANOWSKI, F. C.; VIEIRA, R. D.; FRANÇA NETO, J. B. (Ed.) Vigor de sementes: conceitos e testes. Londrina: ABRATES. 1999. 218p.

NUNES, D. P.; SCALON, S. P. Q.; BONAMIGO, T.; MUSSURY, R. M. Germinação de sementes de marmelo: temperatura, luz e salinidade. Biocience Journal, Uberlândia, v. 30, n. 6, p. 1737-1745, 2014. 
ROCHA, M. A. M.; LACERDA, C. F.; BEZERRA, M. A.; BARBOSA, F. E. L.; FEITOSA, H. O.; SOUSA, C. H. C. Physiological responses of three woody species seedlings under water stress, in soil with and without organic matter. Revista Árvore, Viçosa, v. 40, n. 3, p. 455-464, 2016.

RODRIGUES, V. E. G.; CARVALHO, D. A. Levantamento etnobotânico de plantas medicinais no domínio cerrado na Região do Alto Rio Grande - Minas Gerais. Ciência e Agrotecnologia, Lavras, v. 25, n. 1, p. 102$123,2001$.

SAPETA, H.; COSTA, J. M.; LOURENCO, T.; MAROCO, J.; VAN DER LINDE, P.; OLIVEIRA, M. M. Drought stress response in Jatropha curcas: Growth and physiology. Environmental and Experimental Botany, Oxford, v. 85, p. 76-84, 2013.

SCALON, S. P. Q.; KODAMA, F. M.; DRESCH, D. M.; MUSSURY, R. M.; PEREIRA, Z. V. Gas exchange and photosynthetic activity in Hancornia speciosa gomes seedlings under water deficit conditions and during rehydration. Bioscience Journal, Uberlândia, v. 31, n. 4, p. 1124-1132, 2015.

SCALON, S. P. Q.; JEROMINE, T. S. Substratos e níveis de água no potencial germinativo de sementes de uvaia. Revista Árvore, Viçosa, v. 37, n. 1, p. 49-58, 2013.

SILVA, E. A.; MARUYAMA, W. I.; OLIVEIRA, A. C.; BARDIVIESSO, D. M. Efeito de diferentes substratos na produção de mudas de mangabeira (Hancornia speciosa). Revista Brasileira de Fruticultura, Jaboticabal, v. 31, n. 3, p. 925-929, 2009.

SILVA, C. A.; DOURADO NETO, D.; SILVA, C. J.; FREITAS, C. A. Development of Hymenaea courbaril seedlings in function of containers and irrigation blades. Revista Árvore, Viçosa, v. 40, n. 3, p. 487-498, 2016.

SOUZA, C. C.; OLIVEIRA, F. A.; SIlVA, I. F.; AMORIM NETO, M. S. Avaliação de métodos de determinação de água disponível e manejo da irrigação em terra roxa sob cultivo de algodoeiro herbáceo. Revista Brasileira de Engenharia Agrícola e Ambiental, Campina Grande, v. 4, n. 3, p. 338-342, 2000.

TAIZ, L.; ZEIGER, E. Fisiologia Vegetal. 5. ed. Porto Alegre: Artmed, 2013, 918 p. 